JOURNAL

OF TOURISM

AND ECONOMIC
Journal of Tourism and Economic Vol.4, No.2, 2021, Page 100-118

ISSN: 2622-4631 (print), ISSN: 2622-495X (online)

Email: jurnalapi@gmail.com

Website: http://jurnal.stieparapi.ac.id/index.php/JTEC

DOI: https://doi.org/10.36594/jtec.v4i2.121

\title{
JAJANAN DI MATA MAHASISWA PADA APLIKASI GOFOOD STUDI KASUS: MAHASISWA STIEPAR API YOGYAKARTA
}

\author{
Nuviah Herawati \\ STIE Mitra Indonesia Yogyakarta, INSPECT Multi Konsultan \\ Nuviahherawati@gmail.com \\ Koesharijadi \\ STIE Mitra Indonesia Yogyakarta \\ Yulianto Pudjiwinarno \\ STIE Mitra Indonesia Yogyakarta
}

\begin{abstract}
This study aims to find out what factors encourage consumers to make purchasing decisions culinary products offered through the GoFood application. The research approach uses variables and dimensions of the marketing mix. The marketing mix studied are product, price, distribution and promotion. The study used quantitative methods with regression analysis. Respondents are students of the STIE Tourism API Yogyakarta campus in a certain research period for one month. The measuring instrument used is a questionnaire with the use of a Likert scale. Using the t test, it can be concluded that products and promotions have a significant effect on purchasing decisions through the GoFood application. While price and distribution have no significant effect on purchasing decisions, and with the F-test it is concluded that product, price, distribution, and promotion together have a significant effect on purchasing decisions through the GoFood application.
\end{abstract}

Keywords: marketing mix, product, price, distribution, promotion 


\begin{abstract}
ABSTRAK
Penelitian ini bermaksud mengetahui faktor apa saja yang mendorong konsumen untuk melakukan keputusan pembelian produk kuliner yang ditawarkan melalui aplikasi GoFood. Pendekatan penelitian menggunakan variable-variabel dan dimensi bauran pemasaran. Bauran pemasaran yang diteliti adalah produk, harga, distribusi dan promosi. Penelitian menggunakan metode kuantitatif dengan analisis regresi. Responden adalah mahasiswa kampus STIE Pariwisata API Yogyakarta dalam periode penelitian tertentu selama satu bulan. Alat ukur yang digunakan adalah kuisioner dengan penggunaan skala Likert. Dengan Uji t didapatkan kesimpulan bahwa poduk dan promosi berpengaruh secara signifikan terhadap keputusan pembelian melalui aplikasi GoFood. Sedangkan harga dan distribusi tidk berpengaruh secara signifikan terhadap keputusan pembelian melalui aplikasi GoFood, dan dengan Uji F didapatkan kesimpulan produk, harga, distribusi, dan promosi bersama-sama berpengaruh secara signifikan terhadap keputusan pembelian melalui aplikasi GoFood.
\end{abstract}

Kata kunci : bauran pemasaran, produk, harga, distribusi, promosi 


\section{PENDAHULUAN}

Saat ini teknologi informasi berkembang sangat pesat yang membawa banyak perubahan di berbagai bidang. Salah satunya adalah bidang pemasaran. Kemajuan teknologi memudahkan para produsen dan distributor dalam memasarkan poduk. Oleh karena itu telah terjadi moderasi hubungan antara ketersediaan dan penggunaan informasi, jaringan bisnis internasional dan interaktivitas komunikasi, dan keberhasilan proses bisnis (Skudiene et al., 2015).

Transaksi jual beli melalui jaringan internet/ dalam jaringan/ Daring ini dari waktu ke waktu terus bertambah. Hal ini dibarengi oleh semakin banyaknya pengguna internet di Indonesia. Global Web Index mencatat Indonesia memiliki tingkat pengguna e-commerce tertinggi di dunia. Laporan yang dirilis We Are Social ini menyebutkan $96 \%$ pengguna internet pernah mencari produk atau layanan untuk dibeli secara online (katadata.co.id).

Adapun kunjungan pada toko retail online atau situs terkait dilakukan $91 \%$ dari total pengguna internet. Para pengguna internet juga melakukan pembayaran produk atau layanan online sebesar $90 \%$. Secara berurutan, mereka melakukan pembayaran online melalui ponsel serta laptop atau komputer sebesar $79 \%$ dan 29\% (katadata.co.id). Pesatnya pertumbuhan ini makin menunjukkan posisi penting perdagangan melalui internet dan berbagai aplikasi ikutannya salah satunya adalah aplikasi dalam grup perusahaan Gojek Indonesia yaitu GoFood. GoFood mengkhususkan diri dalam jasa pengiriman produk makanan dan minuman.

GoFood adalah sebuah aplikasi online yang disediakan oleh Gojek yang melayani food delivery service di Indonesia. Mitra GoFood sampai saat ini sudah ribuan jumahnya. Mitra GoFood tidak hanya terdiri dari restauran mewah saja melainkan terdiri dari usaha masyarakat kecil, seperti pedagang kaki lima, hingga makanan hasil karya industri UKM, dan bahkan setiap orang pun bisa menjadi penjual dengan hanya masak dirumah. Di sisi lain GoFood berusaha hadir sebagai perangsang pertumbuhan konsumen. GoFood digunakan sebagai perantara untuk mempermudah pelayanannya sehingga konsumen tidak perlu datang langsung untuk menikmati makannya, juga sebagai sarana untuk memperkenalkan produk baru.

Penelitian ini bertujuan untuk mengetahui aspek bauran pemasaran pada pemasaran makanan melalui aplikasi GoFood di kalangan mahasiswa. Bauran pemasaran yang diteliti adalah variabel produk,harga, distribusi dan promosi terhadap keputusan pembelian produk makanan pada aplikasi GoFood. Analisis yang akan dilakukan adalah pengaruh produk, harga, distribusi, dan promosi terhadap keputusan pembelian melalui aplikasi GoFood.

\section{TINJAUAN LITERATUR}

Menurut The American Marketing Association menyatakan bahwa pemasaran adalah fungsi organisasi dan kesatuan proses untuk menciptakan, mengkomunikasikan, dan mengirim nilai-nilai (perusahaan) kepada pelanggan dan untuk mengelola hubungan dengan pelanggan dengan cara yang menguntungkan bagi perusahaan (kotler, 2012). Meskipun pemasaran masih tentang menciptakan nilai bagi konsumen individu, kini pemasaran juga menyadari pentingnya mitra, dan kebutuhan untuk menciptakan nilai lingkungan dan sosial secara simultan bagi masyarakat luas (Pomering, 2017).

Persepsi konsumen tentang keuntungan relatif, kompleksitas, kompatibilitas, dan risiko yang terlibat dalam pembelian online merupakan hal penting penting dan secara signifikan dimoderasi oleh kenyamanan 
lokasi dan keterlibatan produk (Kim dkk., 2017). Pada tahapan selanjutnya pemasar menyadari akan arti pentingnya memahami para pembeli. Pembeli dalam kontek ecommerce adalah pengguna aplikasi tersebut. Menurut Guiltinan dan Paul (1992) definisi strategi pemasaran adalah pernyataan tentang dampak yang diinginkan akan dicapai dalam hal permintaan pada target pasar yang telah ditentukan. Saat ini Internet dan teknologi Teknologi Informasi (TI) digunakan sebagai pemain strategis, bahkan sebagai pendorong utama dalam keberhasilan bisnis. Ada juga argumen tandingan yang diklaim oleh para peneliti yang menanyakan apakah investasi pada teknologi akan berkelanjutan (Sambhanthan \& Alice, 2016). Pada dasarnya era digital yang menggunakan sarana internet di masa kini perlu mendapat perhatian yang cermat (Priatmoko \& David, 2021).

\section{Produk}

Bauran produk merupakan upaya melakukan diferensiasi pemasaran produk di mata konsumen untuk memudahkan konsumen mengenali produk yang dipasarkan perusahaan (Sadeli dkk., 2016). Produk juga dijadikan sebagai dasar yang mampu berdampak pada konsumsi. Bauran produk merupakan kumpulan dari jenis dan lini produk yang disediakan perusahaan. Atribut produk yang digunakan dalam proses persuasi kepada konsumen untuk model pembelian konvensional dan pembelian daring (online) menggunakan dasar yang sama dalam atribut namun disampaikan kepada konsumen dengan cara berbeda. Produk yang hasilkan oleh perusahaan dapat berupa kombinasi berbagai tingkatan bahan dan proses yang akan memberikan dampak pada perbedaan orientasi perusahaan dalam memproduksi produk tersebut (Pomering, 2017).

\section{Harga}

Perspektif harga bagi konsumen merupakan keseluruhan biaya yang harus dikeluarkan oleh konsumen yang bersifat moneter yang digunakan untuk dapat memiliki, membeli, dan memanfaatkan kombinasi dari produk serta pelayanan yang ditawarkan oleh produk tersebut (Hasan, 2008). Menurut Kotler dan Armstrong (2008) harga adalah sejumlah uang yang harus dibayarkan pelanggan untuk memperoleh produk. Harga adalah mekanisme finansial dimana pendapatan dihasilkan untuk mengimbangi biaya yang dikeluarkan untuk menyediakan layanan serta menciptakan surplus untuk laba (Lovelock, 2011).

Harga adalah kesepakatan nilai yang menjadi persyaratan bagi pertukaran dalam sebuah transakasi pembelian. Menurut (Tjiptono, 2011) harga merupakan "keputusan kritis yang menunjang keberhasilan operasi organisasi profit maupun non-profit." Harga merupakan satusatunya unsur bauran pemasaran yang memberikan pendapatan bagi organisasi. Sehingga harga dapat dijadikan sebagai diferensiasi antara produk persuahaan dengan produk pesaing. Persepsi harga berdampak langsung pada kepuasan dan loyalitas pelanggan. Pelanggan menjadi lebih sensitif terhadap harga dan kurang loyal dengan banyaknya alternatif untuk pemilihan penyedia layanan. Konsumen dapat dengan mudah beralih ke orang lain yang menjanjikan untuk menawarkan kinerja yang lebih baik dengan harga yang lebih rendah karena mereka menilai kelayakan layanan tidak hanya berdasarkan uang tetapi waktu dan juga upayanya (Rathod, 2016).

\section{Distribusi}

Distribusi atau penyaluran merupakan proses atau kegiatan penyampaian produk dari perusahaan sampai ke tangan pelanggan pada waktu yang telah 
ditentukan dengan tepat. Perusahaan dapat menentukan penyaluran produknya melalui perantara atau disebut dengan distributor, akan tetapi perusahaan juga bisa melakukan pendistribusian produknya dengan sendirinya tanpa harus melalui distributor (Abdurahman, 2015). Penyampaian dalam perusahaan jasa harus dapat mencari agen dalam lokasi untuk menjangkau populasi yang tersebar luas Sebagai salah satu variabel marketing mix, yaitu distribusi mempunyai peran yang sangat penting dalam membantu perusaan memastikan produknya, karena tujuan dari distribusi adalah menyediakan barang dan jasa yang dibutuhkan dan diinginkan oleh konsumen pada waktu dan tempat yang tepat. Waktu, konsep yang ada di mana-mana di alam mental dan psikologis individu, memainkan peran penting dalam motivasi dan tindakan konsumen. Meskipun demikian, ini lebih sering daripada tidak diposisikan sebagai variabel samping dalam studi konsumen, ditangani secara implisit atau sepenuhnya diabaikan. Ini menunjukkan bahwa waktu yang sebenarnya selama ini diabaikan menjadi penting dalam era kompetisi pemasaran di era kini ( Gad Mohsen \& Dacko, 2013). Menurut konsep Industri 4.0 ada sistem baru dalam pengembangan produk dan layanan, yang memungkinkan terjadinya perubahan metode distribusi (Lee et al., 2018).

\section{Promosi}

Promosi penjualan adalah kegiatan apa pun yang digunakan oleh produsen untuk mendorong perdagangan (pengecer, grosir, atau rekan jaringan) serta membuat pelanggan membeli merek dan mendorong tenaga penjualan untuk menjualnya secara agresif. Istilah promosi penjualan mengacu pada beberapa jenis insentif dan metode penjualan yang disodorkan untuk menghasilkan efek penjualan langsung (Meo dkk., 2014).
Blattberg dan Neslin dalam Blatberg \& Briesch (2012) mendefinisikan promosi penjualan sebagai "acara pemasaran yang berfokus pada tindakan yang bertujuan untuk memiliki berdampak pada perilaku pelanggan." Ada juga perbedaan penting antara promosi penjualan dan pengurangan harga permanen. Promosi penjualan bersifat sementara dan "panggilan untuk tindakan." Jika pelanggan tidak memanfaatkan promosi dalam jangka waktu yang ditentukan, mereka akan kehilangan manfaat yang ditawarkan oleh promosi. Promosi penjualan hampir selalu digabungkan dengan beberapa jenis komunikasi (misalnya, iklan pengecer) bahwa harga diturunkan/ diskon/ potongan harga dan waktunya periode terbatas (harga dikurangi hanya sampai beberapa titik waktu) (Blattberg \& Briesch, 2012). Ini tentu sangat berbeda dengan variable Harga pada bauran pemasaran yang lain di mana tidak ada pembatasan periode tertentu yang singkat.

Bergantung pada bisnis dan basis pelanggan, perusahaan dapat memilih jenis strategi diskon yaitu: penawaran harga khusus, paket atau bundel, diskon kuantitas, penawaran nilai tambah, diskon musiman atau periodik (business.vic.gov.au). Kesemuanya dibatasi dalam periode dan jumlah tertentu yang jelas. Selain itu penjual melakukan promosi dalam bentuk pengurangan harga atau bonus adalah untuk segera menghabiskan stok mereka. Sebabnya ialah kebijakan harga yang diterepkan sejak awal tidak sesuai dengan ekspektasi pembeli dan penjual. Ini artinya kebijakan terkait dengan penetapan harga khusus pada promosi sangat berbeda dengan kebijakan variabel harga pada bauran pemasaran. Diskon pada pada program promosi akan mengambil alih peran tersebut dengan membuat pembeli merasa rasional dengan harga atau barang yang diberikan pada program promosi (Armstrong \& Chen, 2017). Saat diskon diumumkan intensitasnya oleh pejual melalui iklan promosi maka persepsi 
konsumen juga akan meningkat (Gupta \& Cooper, 1992).

\section{Keputusan Pembelian}

Sumarwan (2003) menyatakan pembelian merupakan keputusan konsumen menyangkut apa yang dibeli, apakah membeli atau tidak, kapan membeli, di mana membeli, dan bagaimana cara pembayarannya. sehingga dapat disimpulkan bahwa keputusan pembelian merupakan keputusan atas suatu tindakan yang diambil dari dua atau lebih pilihan tentang proses, cara, perbuatan membeli, dengan mempertimbangkan fator-faktor tentang apa yang dibeli, waktu membeli, dimana membelinya serta cara pembayarannya. keputusan konsumen sebagai suatu tindakan yang diambil dari dua atau lebih pilihan alternatif. Proses keputusan pembelian melalui cara pengenalan kebutuhan, pencarian informasi, evaluasi alternatif, pembelian, dan perilaku pasca pembelian. mengakibatkan suatu pembelian dipengaruhi oleh rangsangan. Maka dari itu dikatakan bahwa ada konsumen yang mempunyai keterlibatan tinggi dalam pembelian suatu produk atau jasa, dan ada juga konsumen yang mempunyai keterlibatan yang rendah atas pembelian suatu produk atau jasa. (Mowen dan Minor, 2002).

Perilaku konsumen adalah proses ketika orang "memilih, membeli, menggunakan atau membuang produk, layanan, ide atau pengalaman untuk memuaskan kebutuhan dan keinginannya serta mencari tahu "mengapa orang membeli" sesuatu (Spáčil \& Teichmannová, 2016). Peluncuran sebuah produk ke pasar, produsen harus mampu memahami perilaku komsumen yang akan menjadi target mereka serta proses yang dilakukan dalam pengambilan keputusan pembelinya (Suzy, 2008). Pada masa sekarang konsumen makin sadar juga akan arti penting makanan misalnya terkait dengan kesehatan karena perubahan suasana kerja dan pengaruh grupgrup sosial. Hal ini menjadikan mereka juga makin peduli atas apa yang mereka makan beserta kandungannya (Begum, 2015).

Mahasiswa adalah bagian dari usia produktif yang melakukan banyak transaksi. Data menunjukan dari keseluruhan transaksi online dilakukan oleh masyarakat, mayoritas (53\%) dilakukan oleh pemuda (Nielsen company, 2019). Hal ini tentu saja karena didukung oleh pemahaman mereka akan teknologi informasi. Anak muda yang dibesarkan di era digital memang berbeda dengan generasi tua. Sehingga kelompok anak muda perlu dicermati dan dianalisa, agar penawaran perusahaan dapat menyesuaikan dengan kebutuhan mereka (Kowalska, 2012). Lebih jauh lagi, mahasiswa pariwisata dianggap bisa lebih kritis memahami industri makanan karena materi tentang makanan dan minuman/ food and beverage menjadi kurikulum yang diajarkan di perkuliahan (Buted et al., 2014). Selain banyaknya mahasiswa, lokasi Kawasan Babarsari yang berada di Kabupaten Sleman merupakan Kawasan yang memiliki banyak pengusaha dan Usaha Mikro, Kecil, dan Menengah/ UMKM bidang makanan/ minuman. Hal tersebut dibuktikan dengan data awal yang didapat dari pengamatan lapangan di sekitar kawasan kampus di Babarsari. Oleh karena itu mahasiswa kampus STIE Pariwisata API dapat memenuhi kedua kriteria tersebut dan dianggap akan dapat memberikan gambaran yang lebih obyektif bagi penjual makanan di aplikasi GoFood. tersebut. Sehingga terjadi keputusan pembelian.

Peneliti menggunakan pedekatan Bauran pemasaran yang merupakan salah satu strategi marketing untuk mempengaruhi pembeli melakukan transaksi online untuk membeli makanan penjual tersebut sehingga dapat meningkatkan penjualan para pelaku bisnis kuliner melalui media online GoFood. Bauran pemasaran merupakan variabel- 
variabel yang dapat dikendalikan dan digunakan perusahaan untuk mempengaruhi tanggapan pendapat konsumen akan produk tersebut dari segmen pasar tertentu yang diinginkan oleh perusahaan. Bauran pemasaran yang terdiri dari produk, harga, lokasi, dan promosi merupakan alat strategi suatu perusahaan dalam pemasaran yang penerapannya memerlukan pemahaman mendalam dari perusahaan untuk mengkombinasikan faktor-faktor tersebut untuk memaksimalkan kesuksesan aktivitas pemasaran perusahaan (Hintze, 2015).

Strategi bauran pemasaran (marketing mix) yang terdiri antara lain dari strategi produk, penetapan harga, distribusi dan promosi dalam segmen pasar yang diketahui cocok untuk memahami skala multi dimensi untuk mengidentifikasi dimensi yang mendasari (Kusrini dan Kismanto, 2011). Nielsen (2019) juga menganggap faktorfaktor yang berkontribusi dalam marketing mix termasuk kemasan tematik yang menarik, inovasi varian, peningkatan distribusi, variasi jangkauan, dan harga yang terjangkau (Nielsen company, 2019). Bauran pemasaran juga dipercaya sebagai sebagai seperangkat alat pemasaran taktis dan terkontrol yang dipadukan oleh perusahaan untuk menghasilkan respons yang diinginkan oleh pasar sasaran (Kotler dan Amstrong, 2001).

Selain beberapa tinjauan referensi di atas, kami juga melakukann studi Pustaka atas penelitian-penelitian terdahulu diantaranya:

1. Suzy Widyasari dan Erna Triastuti Fifilia (2009) dalam penelitiannya yang berjudul Analisis pengaruh produk, harga, promosi dan lokasi terhadap keputusan pembelian rumah (studi pada perumahan graha estetika semarang) menyatakan bahwa terdapat pengaruh signifikan produk, harga, promosi dan lokasi terhadap keputusan pembelian rumah di Perumahan Graha Estetika Semarang.
2. Fiera Aryati Natakusumah, Ai Lili Yuliati (2016) dalam penelitiannya yang berjudul Pengaruh bauran pemasaran terhadap keputusan pembelian (studi pada ina cookies bandung) menyatakan bahwa terdapat pengaruh positif signifikan produk, harga, promosi dan lokasi terhadap keputusan pembelian kue di Ina cookies Bandung.

3. Norrahmiati (2016) dalam penelitiannya yang berjudul Analisis pengaruh bauran pemasaran terhadap keputusan pembelian mobil suzuki ertiga di dealer suzuki banjarmasin menyatakan bahwa produk, harga, tempat, promosi, proses dan bukti fisik berpengaruh signifikan terhadap keputusan pembelian sedangkan variabel personel berpengaruh tidak signifikan terhadap keputusan pembelian.

4. Rionardo Prasetio dan Kazia Laturette (2017) dalam penelitiannya yang berjudul Pengaruh bauran pemasaran terhadap keputusan pembelian pada bisnis chepito tour \& travel menyatakan bahwa Produk,tempat dan promosi berpenaruh signifikan terhadap keputusan pembelian sedangkan harga berpengaruh tidak signifikan terhadap keputusan pembelian.

5. Fazza Ilham Fachriza, Nadya Moeliono (2017) dalam penelitiannya yang berjudul Pengaruh Bauran Pemasaran Terhadap Keputusan Pembelian Rokok Mild menyatakan bahwa produk dan tempat berpengaruh secara signifikan terhadap keputusan pembelian rokok Mild sedangkan harga dan promosi tidak berpengaruh signifikan terhadap keputusan pembelian.

6. Oktavianus Barcelona, Tinneke $\mathrm{M}$. Tumbel, John A. F. Kalangi (2019) dalam penelitiannya yang berjudul Pengaruh Marketing Mix Terhadap Keputusan Pembelian Pada CV. Justiti Motor Lembata menyatakan bahwa Marketing mix berpengaruh terhadap keputusan pembelian. 
7. Deny Faizal Noor, Indah Rahmawati (2020) ) dalam penelitiannya yang berjudul Pengaruh Marketing mix Terhadap keputusan PembelianFurnitur Pada PT. Catur Sentosa Berhasil menyatakan bahwa Marketing mix berpengaruh terhadap keputusan pembelian.

8. Giri Dwinanda, Yuswari Nur (2020) dalam penelitiannya yang berjudul Bauran pemasaran $7 \mathrm{p}$ dalam mempengaruhi keputusan pembelian konsumen pada industri Retail giant ekspres makassar menyatakan bahwa hanya Price yang berpengaruh signifikan terhadap keputusan pembelian sedangkan produk, promotion, Place, people,process, physical evidence berpengaruh tidak signifikan terhadap keputusan pembelian.

Dari tinjauan Pustaka tersebut selanjutnya dijadikan landasan untuk membangun hipotesis atas keputusan pembelian pada perilaku konsumsi generasi muda (mahasiswa) saat menggunakan aplikasi digital.

\section{METODE PENELITIAN}

\section{Jenis Penelitian dan Obyek Penelitian}

Penelitian ini menggunakan metode regresi linear untuk menguji pengaruh variabel independent terhadap variable dependen. Dalam penelitian ini, data diperoleh dengan menyebarkan kuesioner. Kuesioner di desain sedemikian rupa menggunakan aplikasi formulir digital Google Form dari perusahaan Google.com sehingga diharapkan semua responden dapat menjawab semua pertanyaan. Kuesioner yang disebarkan berasal dari tiga sumber. Sumber yang pertama yaitu kuesioner yang digunakan dalam penelitian ini tentang pengaruh produk terhadap keputusan pembelian. Sumber kedua yaitu kuesioner yang digunakan tentang pengaruh harga terhadap terhadap keputusan pembelian.
Sumber yang ketiga adalah kuesioner tentang pengaruh tempat terhadap terhadap keputusan pembelian. Sumber yang keempat adalah kuisioner tentang pengaruh promosi terhadap terhadap keputusan pembelian.

Penelitian ini dilaksanakan Kampus STIE Pariwisata API Yogyakarta selanjutnya disingkat STIEPAR API yang beralamat di Jl, Glendongan TB. XV/15b, Sleman, D I Yogyakarta. Sampel yang digunakan adalah para mahasiswa dengan jumlah responden yang diambil menggunakan pendekatan rumus Slovin (Riduwan, 2008) sebagai berikut:

$$
\mathrm{n}=\mathrm{N} /\left(1+\mathrm{N} e^{2}\right)
$$

Keterangan :

n : Jumlah Sampel

$\mathrm{N}$ : Jumlah Populasi

e : Batas kesalahan maksimal yang ditolerir dalam sampel (5\%)

\section{Tehnik Analisis Data Uji Instrument}

Pada penelitian ini uji validitas menggunakan teknik korelasi Product Moment dari Pearson. Sugiyono (2002) menyatakan bahwa syarat untuk dianggap memenuhi kriteria valid, apabila $r$ hitung $>r$ tabel, maka data dikatakan valid. Dari setiap item pertanyaan diperoleh besaran korelasi ( $\mathrm{r}$ hitung) lebih besar dari tabel korelasi. Untuk menguji reliabilitas dari kuisioner dipergunakan teknik Cronbach Alpha (koefisien alpha), dengan $\alpha \dot{\alpha}>0,60$, sehingga dapat disimpulkan bahwa instrumen yang dipergunakan dalam penelitian ini memiliki tingkat reliabilitas yang cukup memadai Pengukuran reliabilitas.

\section{Uji Asumsi dan Uji Hipotesis Uji Normalitas}

Walaupun normalitas suatu data tidak terlalu penting, tetapi sebaiknya data yang ada beristribusi normal (Ghozali, 2009). Jika 
data berdistribusi normal maka dianggap dapat mewakili populasi (Duwi, 2010). Untuk menguji semua variabel tersebut berdistribusi normal dapat dilkukan dengan cara melihat hasil output SPSS uji Kolmogorov-Smirnov $Z$.

\section{Uji Multikolinearitas}

Menurut Hair (Duwi,2010), variabel yang menyebabkan multikolinearitas dapat dilihat dari nilai toleransi yang lebih kecil dari 0,1 atau nilai VIF yang lebih besar dari nilai 10.

\section{Uji Heteroskedastisitas}

adalah varian residual yang tidak sama pada semua variabel bebas di dalam model regresi. Dimana regresi yang baik seharusnya tidak terjadi heteroskedasitas (Duwi,2010)

Untuk mendeteksi ada tidaknya heteroskedastisitas, dapat dilakukan dengan berbagai cara yaitu uji Spearman's Rank dengan cara mengkorelasikan variabel independen dengan nilai unstandardized residual.

\section{Uji Hipotesis}

Uji $F$ digunakan untuk menguji besarnya pengaruh dari seluruh variabel independen terhadap variabel dependen.

\section{Uji Koefisien Determinasi (uji $\mathbf{R}^{\mathbf{2}}$ )}

Menurut Sugiono (2002), kofisien Determinasi $\left(\mathrm{R}^{2}\right)$ digunakan untuk mengukur seberapa jauh kemampuan model dalam menerangkan variabel dependen.

\section{Regresi Berganda}

Analisis regresi berganda bertujuan untuk memprediksi nilai pengaruh empat variabel bebas terhadap satu variabel terikat dengan menggunakan persamaan regresi sebagai berikut :

$$
\mathrm{Y}=\mathrm{a}+\mathrm{b} 1 \mathrm{X} 1+\mathrm{b} 2 \mathrm{X} 2+\mathrm{b} 3 \mathrm{X} 3+\mathrm{b} 4 \mathrm{X} 4
$$

Keterangan :

Y : Keputusan Pembelian

a : konstanta

b1,b2,b3,b4 : Koefisien regresi variabel bebas

X1 : Produk

X2 : Harga

$\mathrm{X} 3$ : Distribusi

$\mathrm{X} 4$ : Promosi

Secara garis besar alur penelitian ini dapat digambarkan pada gambar diagram $1 \mathrm{di}$ bawah ini.

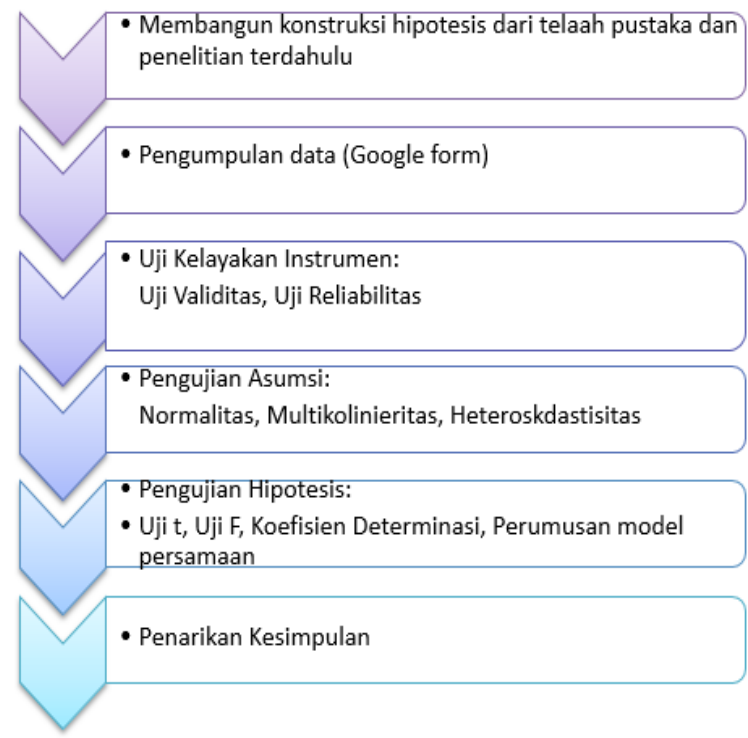

Gambar 1. Diagram alur proses penelitian/ research flows

Sumber: Penulis, 2021

\section{HASIL DAN PEMBAHASAN}

Dari hasil telaah Pustaka dan penelitian-penelitian terdahulu, peneliti membangun konstruksi hipotesis sebagai berikut:

\section{Pengaruh Produk Terhadap}

Keputusan Pembelian melalui aplikasi GoFood

Kotler (2009) berpendapat bahwa keputusan membeli adalah tahapan-tahapan yang dilakukan oleh konsumen sebelum melakukan memutuskan membeli suatu 
produk. Keputusan untuk membeli oleh konsumen tersebut dapat dipengaruhi oleh kualitas produk dan citra merek. Dalam jangka panjang perusahaan tersebut akan lebih berhasil dari perusahaan yang lain (Oktavenia dan Ardani, 2019). Selain itu menurut Zulaicha dan Irawati (2016) produk yang dijual harus mempunyai kualitas yang baik, unik dan penampilan yang menarik sehingga dapat membuat konsumen tertarik untuk membeli. Hal ini menunjukkan bahwa ada hubungan antara produk terhadap keputusan pembelian. Penelitian ini didukung oleh Norrahmiati (2016) yang menyimpulkan bahwa produk berpengaruh secara signifikan terhadap keputusan pembelian.

Berdasarkan uraian diatas maka dirumuskan hipotesis penelitian sebagai berikut:

H1: Diduga Produk Berpengaruh Signifikan Terhadap Keputusan Pembelian Melalui Aplikasi Gofood Oleh Mahasiswa Stiepar Api

\section{Pengaruh Harga Terhadap Keputusan Pembelian melalui aplikasi GoFood}

Menurut Zulaicha dan Irawati (2016) harga adalah salah satu cara bagi penjual untuk melihat perbedaan penawaran dari para pesaing. Sehingga penetapan harga dapat dianggap sebagai bagian dari fungsi pembeda posisi barang dalam pemasaran.

Swastha (2014) menyatakan bahwa dalam pemasaran, menentukan harga adalah salah satu cara untuk memenuhi kepuasan pelanggan dalam memutuskan pembelian. Jika seorang pembeli mempunyai kesempatan untuk membeli barang dan jasa yang sama dengan harga lebih rendah, maka ia akan mengambil kesempatan tersebut. Harga menurut Kotler dan Amstrong (2012) adalah sejumlah nilai yang konsumen tukarkan untuk jumlah manfaat dengan memiliki atau menggunakan suatu barang atau jasa.
Harga juga secara parsial positif dan berpengaruh secara signifikan terhadap keputusan pembelian (Igir dkk., 2018). Sehingga dalam hal ini harga menjadi faktor yang ikut menentukan terjadinya transaksi. Menurut Rahmadani dan Ananda (2018) harga berpengaruh positif signifikan terhadap keputusan pembelian di toko yang menjual melalui online shop. Wachyuni, dkk (2018) juga menyatakan bahwa distribusi melalui online juga mempengaruhi perilaku pembeli.

Hasil Penelitian ini didukung oleh Giri Dwinanda Yuswari Nur, 2020 yang menyimpulkan harga berpengaruh terhadap keputusan pembelian. Dengan melihat uraian diatas maka hipotesis penelitian dapat dirumuskan sebagai berikut:

H2:Diduga harga berpengaruh signifikan terhadap keputusan pembelian melalui aplikasi GoFood oleh mahasiswa Stiepar Api

\section{Pengaruh Tempat/Distribusi Terhadap Keputusan Pembelian melalui aplikasi GoFood}

Penelitian ini didukung oleh Rionardo Prasetio dan Kazia Laturette (2017) yang menyimpulkan distribusi berpengaruh signifikan terhadap keputusan pembelian. Demikian juga dengan Fiera Aryati Natakusumah, Ai Lili Yuliati (2016) yang menyimpulkan lokasi berpengaruh signifikan terhadap keputusan pembelian.

Dengan melihat uraian diatas maka hipotesis penelitian dapat dirumuskan sebagai berikut:

H3: Diduga distribusi berpengaruh signifikan terhadap keputusan pembelian melalui aplikasi GoFood oleh mahasiswa Stiepar Api

\section{Pengaruh Promosi Terhadap Keputusan Pembelian melalui aplikasi GoFood}


Menurut Simamora (2002) kegiatan promosi tidak hanya berfungsi sebagai alat komunikasi antara perusahaan dengan konsumen, tetapi juga dimaksudkan untuk mempengaruhi konsumen dalam kegiatan pembelian atau penggunaan jasa sesuai dengan keinginan dan kebutuhannya. Wulandari (2012) juga menyimpulkan bahwa Promosi berpengaruh positif dan signifikan terhadap keputusan pembelian.

Dengan melihat uraian diatas maka hipotesis penelitian dapat dirumuskan sebagai berikut:

H4: Diduga promosi berpengaruh signifikan terhadap keputusan pembelian melalui aplikasi GoFood oleh mahasiswa Stiepar Api

\section{Pengaruh produk, harga, distribusi dan promosi terhadap keputusan pembelian}

Keputusan pembelian merupakan tindakan-tindakan yang meliputi keputusan tentang jenis produk, merek, harga, kualitas, kuantitas, waktu pembelian dan cara pembayarannya (Swasta dan Irawan, 2014). Hasil penelitian ini didukung oleh Suzy Widyasari dan Erna Triastuti Fifilia (2009) menyimpulkan bahwa produk, harga, lokasi, dan promosi berpengaruh positif dan signifikan terhadap keputusan pembelian.

Dengan melihat uraian diatas maka hipotesis penelitian dapat dirumuskan sebagai berikut:

H5: Diduga produk, harga, distribusi dan promosi secara bersama-sama berpengaruh signifikan terhadap keputusan pembelian melalui aplikasi GoFood oleh mahasiswa Stiepar Api

\section{Populasi dan Sampel}

Populasi Penelitian Dari informasi yang diperoleh dari pengelola kampus STIE Pariwisata API Yogyakarta diketahui jumlah mahasiswa adalah 257 orang. Dari populasi tersebut di atas maka dipergunakan rumus Slovin untuk menghitung sampel dari populasi di atas 257 sehingga menggunakan tingkat signifikansi $\quad 0,1 \quad(10 \%)$. Perhitungannya sbb.:

$$
\mathrm{n}=\frac{257}{1+257(0,1)^{2}}=257 / 1+(257 \times 0,01)=71,9
$$

Dari perhitungan didapatkan angka 71,9 minimal responden dan dibulatkan menjadi 72 mahasiswa. Namun demikian saat dilakukan pengumpulan data didapatkan 98 jumlah sampel yang layak sehingga keseluruhannya diambil dalam penelitian ini menjadi 98 (Sembilan puluh delapan) responden.

\section{Uji Kelayakan Instrumen}

\section{Uji Validitas}

Uji Validitas dilakukan untuk mengetahui kevalidan atau kesesuaian kuisioner dalam penelitian. Dalam pengujian Validitas dari kuisioner digunakan Uji Validitas Product moment Person correlation dengan prinsip mengkorelasikan atau menghubungkan skor total dari masing masing variabel yang diperoleh dari jawaban responden. dihasilkan output-output sebagai berikut:

Tabel 1 Hasil Uji Validitas

\begin{tabular}{cccc}
\hline No. & R Hitung & R Tabel & Keterangan \\
\hline 1 & 0,492 & 0,197 & Valid \\
2 & 0,589 & 0,197 & Valid \\
3 & 0,640 & 0,197 & Valid \\
4 & 0,732 & 0,197 & Valid \\
5 & 0,701 & 0,197 & Valid \\
6 & 0,768 & 0,197 & Valid \\
7 & 0,820 & 0,197 & Valid \\
8 & 0,703 & 0,197 & Valid \\
9 & 0,835 & 0,197 & Valid \\
10 & 0,877 & 0,197 & Valid \\
11 & 0,939 & 0,197 & Valid \\
12 & 0,942 & 0,197 & Valid \\
\hline
\end{tabular}

Sumber: Data diolah, 2021 
Berdasarkan tabel 1 diperoleh hasil $\mathrm{R}$ hitung lebih besar dari pada $\mathrm{R}$ tabel. Hal ini menunjukkan bahwa indikator dinyatakan valid

\section{Uji Reliabilitas}

Uji reliabilitas hanya dilakukan pada item-item pernyataan kuesioner yang telah valid. Adapun hasil perhitungan uji reliabilitas disajikan pada tabel 2 di bawah.

Tabel 2 Hasil Uji Reliabilitas

\begin{tabular}{lcc}
\hline Variabel & $\begin{array}{l}\text { Cronbach's } \\
\text { Alpha }\end{array}$ & Keterangan \\
\hline Produk & 0,618 & Reliabel \\
Harga & 0,631 & Reliabel \\
Distribusi & 0,633 & Reliabel \\
Promosi & 0,869 & Reliabel \\
Keputusan & 0.689 & Reliabel \\
Pembelian & & \\
\hline
\end{tabular}

Sumber: Data diolah, 2021

\section{Pengujian Asumsi Normalitas}

Uji normalitas yang dilakukan dengan menggunakan One-Sample KolmogorovSmirnov Test. Adapun hasil perhitungan uji normalitas disajikan pada tabel 3 .

Tabel 3 Hasil Uji Normalitas Dengan OneSample Kolmogorof-Smirnov Test Unstandardized Residual

Asymp. $\quad 0,200$

Sig. (2-

tailed)

Sumber: data diolah, 2021

Dari output diatas didapatkan hasil Asymp.sig.(2-tiled) $0.200>0,05$ maka data penelitian tersebut berdistribusi normal.

\section{Multikolinieritas}

Untuk menguji apakah didalam model regresi dtemukan adanya korelasi atau hubungan yang kuat antar variabel Model regresi yang baik adalah tidak terjadinya multikolinieritas. Dari pengujian SPSS maka diperoleh output sebagai berikut:

Tabel 4. Uji Multikolinieritas

\begin{tabular}{lrc}
\hline Variabel & Tolerance & VIF \\
\hline Produk & 0,799 & 1,251 \\
Harga & 0,855 & 1,169 \\
Distribusi & 0,846 & 1,183 \\
Promosi & 0,758 & 1,320 \\
\hline
\end{tabular}

Sumber: Data diolah, 2021

Dari output yang dihailkan diatas nilai Tolerance > 0,1 dan VIF (Variance Inflation factor) < 10 maka dapat disimpukan bahwa tidak terjadi masalah multikolinieritas.

\section{Heteroskdastisitas}

Pengujian Heteroskedastisitas dilakukan untuk mengetahui apakah dalam model regresi ada ketidaksamaan variansi dari nilai residual Variabel bebas. Model regresi yang baik seharusnya tidak terjadi heterokedastisitas. Pengujian heteroskedastisitas dilakukan dengan uji spearman's rho menggunakan SPSS dan dihasilkan output sebagai berikut:

Tabel 5. Uji Heteroskedastisitas

\begin{tabular}{lc}
\hline Variabel & Nilai Sig. \\
\hline Produk & 0,810 \\
Harga & 0,754 \\
Distribusi & 0,920 \\
Promosi & 0,974 \\
\hline
\end{tabular}

Sumber: data diolah, 2021

Dari output diatas didapatkan nilai sig(.2-tailed) Pada variabel Produk, Harga, Distribusi, Promosi > 0.05 maka tidak terjadi heteroskedastisitas.

\section{Pengujian Hipotesis}

Uji t

Uji $\mathrm{t}$ digunakan untuk mengetahui apakah terdapat pengaruh Produk, Harga, Distribusi dan Promosi secara parsial terhadap keputusan pembelian. Dengan 
menggunakan SPSS maka didapatkan Output sebagai berikut:

Tabel 6. Uji parsial (Uji t)

\begin{tabular}{cc}
\hline & Sig. \\
\hline konstanta & 0,965 \\
Produk & 0,010 \\
Harga & 0,885 \\
Distribusi & 0,450 \\
Promosi & 0,000 \\
\hline
\end{tabular}

Sumber: data diolah, 2021

Nilai Sig. $0,010<0.05$ dapat disimpulkan bahwa Ho ditolak dan $\mathrm{Ha}$ diterima artinya Produk berpengaruh signifikan terhadap keputusan pembelian. Nilai Sig. $0.885>0.05$ dapat disimpulkan bahwa Ho diterima dan Ha ditolak artinya Harga tidak berpengaruh signifikan terhadap keputusan pembelian.Nilai Sig. $0.450>0.05$ dapat disimpulkan bahwa Ho diterima Ha ditolak artinya Ditribusi tidak berpengaruh signifikan terhadap keputusan pembelian. Nilai sig. $0.000<0.05$ dapat disimpulkan bahwa Ho ditolak maka Promosi berpengaruh signifikan terhadap keputusan pembelian

\section{Uji F}

Uji F di gunakan untuk mengetahui pengaruh Variabel bebas secara bersamasama terhadap variabel terikat. berikut adalah output ANOVA dimana terdapat nilai $\mathrm{F}$ didalamnya.

\begin{tabular}{ccc} 
& \multicolumn{2}{c}{ Tabel 7. Anova (Uji F) } \\
\hline & $\mathrm{F}$ & Sig. \\
\hline regression & 21,962 & 0,000 \\
\hline
\end{tabular}

Sumber: data diolah, 2021

Nilai Fhitung > Ftabel yaitu 21,962 > 2.47 dan Nilai sig. $0.00<0.05$ maka dapat disimpulkan bahwa Ho ditolak dan $\mathrm{Ha}$ diterima artinya Produk, Harga, distribusi, Promosi secara bersama-sama berpengaruh secara signifikan terhadap keputusan pembelian.
Koefisien Determinasi $\left(\mathbf{R}^{\mathbf{2}}\right)$

Untuk mengetahui seberapa besar variabel independen dapat menjelakan variabel dependen. Dengan menggunakan SPSS maka didapatkan Output dibawah ini:

Tabel 8. Koefisien determinasi

\begin{tabular}{ll}
\hline R Square & 0,486 \\
Adjusted R Square & 0,464 \\
\hline Sumber: data diolah &
\end{tabular}

Berdasarkan output diatas didapatkan nilai adjusted $R$ square (koefisien determinasi) 0,464 artinya Variabel independen dapat menjelaskan variabel dependen sebesar 46,4 persen.

\section{Persamaan Regresi Berganda}

Persamaan regresi berganda dapat dilihat dari nilai koefisien regesi sebagai berikut:

Tabel 9. Koefisien regresi berganda

\begin{tabular}{ll}
\hline Variabel & Koefisien \\
\hline Konstanta & 0,78 \\
Produk (X1) & 0,214 \\
Harga (X2) & $-0,015$ \\
Distribusi (X3) & 0,102 \\
Promosi X4) & 1,115 \\
\hline
\end{tabular}

Sumber: data diolah, 2021

Berdasarkan hasil pengolahan data dapat dirumuskan model persamaan regresi berganda sebagai berikut:

$\mathrm{Y}=\mathrm{a}+\mathrm{b} 1 \mathrm{X} 1+\mathrm{b} 2 \mathrm{X} 2+\mathrm{b} 3 \mathrm{X} 3+\mathrm{b} 4 \mathrm{X} 4$

$\mathrm{Y}=0,78+0,214 \mathrm{X} 1-0,015 \mathrm{X} 2+0,102 \mathrm{X} 3+1,115 \mathrm{X} 4$

Apabila variabel produk, harga, tempat, dan promosi bernilai nol maka keputusan pembelian bernilai 0,78 satuan. Jika variabel produk ditingkatkan 1 satuan maka keputusan pembelian akan bertambah 0,214 dengan asumsi variabel harga, distribusi dan promosi tetap. Jika variabel harga ditingkatkan sebesar 1 satuan, maka 
keputusan pembelian akan berkurang sebesar 0,015 dengan asumsi variabel produk, distribusi dan promosi tetap. Jika variabel distribusi ditingkatkan sebesar 1 satuan maka keputusan pembelian akan bertambah sebesar 0,102 dengan asumsi variabel produk, harga dan promosi tetap. Jika variabel promosi ditingkatkan sebesar 1 satuan maka keputusan pembelian akan bertambah sebesar 1,115 dengan asumsi variabel produk, harga dan distribusi tetap.

Dari hasil perhitungan dan analisis data dengan bantuan aplikasi SPSS versi 22 di atas selanjutnya dilakukan interpretasi sebagai berikut:

\section{Pengaruh Produk Terhadap Keputusan Pembelian}

Pengujian secara persial menunjukkan bahwa produk terbukti berpengaruh secara signifikan terhadap keputusan pembelian. Hal ini dapat dilihat dari nilai sig. Produk sebesar 0,010 < 0,05 maka Ho ditolak dan Ha diterima artinya produk berpengaruh positif dan signifikan terhadap keputusan pembelian.

Dengan diterimanya hipotesis awal menunjukkan bahwa dengan tampilan (gambar makanan yang dtampilkan di aplikasi), ukuran porsi makanan, kemasan dari makanan, pilihan rasa, dan macam tambahan toping dari makanan tersebut membuat mahasiswa melakukan keputusan pembelian makanan melalui GoFood. Hal ini sejalan dengan upaya penjual makanan dengan melakukan berbagai rekayasa tampilan produk maupun foto-foto yang disajikan atas produk yang mereka jual pada aplikasi GoFood. Ini tentunya menjadi petunjuk bahwa bauran pemasaran pada aspek produk masih menjadi hal yang penting bagi konsumen. Kekuatan citra produk juga mendukung terjadinya keinginan untuk membeli bagi konsumen ((Priatmoko \& Lóránt, 2021). Hal-hal yang terkait dengan gambar makanan yang dtampilkan di aplikasi, ukuran porsi makanan, kemasan dari makanan, pilihan rasa, dan macam tambahan toping dari makanan tersebut nyata-nyata membuat konsumen melakukan keputusan pembelian makanan melalui GoFood.

Penelitian ini didukung oleh penelitian yang dilakukan oleh Norrahmiati (2016) yang menyimpulkan bahwa produk berpengaruh secara signifikan terhadap keputusan pembelian. Hasil penelitian ini tidak sejalan dengan penelitian yang dilakukan oleh Giri Dwinanda Yuswari Nur (2020) yang menyimpulkan bahwa produk tidak mempunyai pengaruh yang signifikan terhadap keputusan pembelian.

\section{Pengaruh Harga Tehadap Keputusan Pembelian}

Dari pengujian parsial menunjukkan bahwa harga terbukti tidak berpengaruh signifikan terhadap keputusan pembelian. Dapat dilihat dari nilai sig. harga sebesar 0,885 > 0,05 maka Ho diterima dan $\mathrm{Ha}$ ditolak artinya harga tidak berpengaruh secara signifikan terhadap keputusan pembelian.

Hipotesis awal ditolak hal ini dimungkinkan karena pembeli lebih memikirkan produknya dari pada harganya, karena bagi sebagian besar orang harga sesuai dengan produk yang dibelinya. Pembeli juga telah memahami bahwa membeli makanan melalui aplikasi online lebih mahal dibandingkan jika membeli langsung di lokasi penjual. Dalam era digital dan keterbukaan informasi seperti sekarang ini konsumen sudah dapat berpikir bahwa produk yang baik umumnya dijual dengan harga yang relative lebih mahal. Dengan demikian konsumen telah mengetahui bahwa secara umum harga berbanding lurus dengan kualitas produk.

Telah dijelaskan pada pendahuluan dan juga pada diskriptif responden menunjukkan kemampuan daya beli generasi milenial (diumur awal 20-an) yang merupakan first 
jobbers dan masih bisa menggunakan seluruh pendapatan tersebut untuk dirinya sendiri mencukupi untuk membeli produk-produk yang ditawarkan pada aplikasi online. Dengan demikian harga khususnya harga makanan tidak terlalu berpengaruh menjadi pertimbangan dalam pembelian.

Selain itu, pemakluman adanya ongkos kirim yang menambah komponen harga pembelian juga sudah menjadi hal yang mahfum. Dengan kata lain, karakteristik pembeli makanan melalui GoFood bukanlah konsumen yang sangat sensitif atas harga yang ditawarkan di aplikasi.

Penelitian ini didukung oleh penelitian yang dilakukan oleh Rionardo Prasetio dan Kazia Laturette (2017) yang menyimpulkan bahwa harga tidak berpengaruh signifikan terhadap keputusan pembelian. Hasil penelitin ini tidak sejalan dengan hasil penelitian dari Suzy Widyasari dan Erna Triastuti Fifilia (2009) yang menyimpulkan bahwa harga berpengaruh signifikan terhadap keputusan pembelian.

\section{Pengaruh Distribusi Terhadap Keputusan Pembelian}

Pengujian secara persial menunjukkan bahwa distribusi terbukti tidak berpengaruh secara signifikan terhadap keputusan pembelian. Hal ini dapat dilihat dari nilai sig. distribusi sebesar $0,450>0,05$ maka Ho diterima dan $\mathrm{Ha}$ ditolak artinya tidak berpengaruh signifikan terhadap keputusan pembelian.

Distribusi tidak terlalu berpengaruh terhadap jarak tempuh dan waktu dimungkinkan karena proses perolehan makanan telah dilakukan oleh mitra/ driver GoFood dan bukan oleh pembeli, pembeli hanya tinggal menunggu dirumah/ditempatnya maka usaha tersebut tidak mempengaruhi secara signifikan perilaku pembeli. Penerimaan atas lamanya waktu tempuh yang telah diketahui oleh konsumen dan disadari sejak awal menjadikan jarak dan waktu menjadi tidak terlalu penting bagi konsumen. Jauh ataupun dekat lokasi penyedia/ penjual makanan telah ditangani/ di-cover oleh driver GoFood.

Penelitian ini didukung oleh penelitian yang dilakukan oleh Giri Dwinanda Yuswari Nur (2020) yang menyimpulkan bahwa tempat tidak mempunyai pengaruh yang signifikan terhadap keputusan pembelian. Hasil penelitin ini tidak sejalan dengan hasil penelitian dari Fazza Ilham Fachriza, Nadya Moeliono (2017) yang menyimpulkan bahwa tempat berpengaruh signifikan terhadap keputusan pembelian.

\section{Pengaruh Promosi Terhadap Keputusan Pembelian}

Pengujian secara persial menunjukkan bahwa promosi terbukti berpengaruh secara signifikan terhadap keputusan pembelian. Hal ini dapat dilihat dari nilai sig. promosi sebesar 0,000 > 0,05 maka Ho ditolak dan $\mathrm{Ha}$ diterima artinya promosi berpengaruh signifikan terhadap keputusan pembelian.

Hipotesis awal diterima, didapati fakta bahwa ternyata kebanyakan konsumen akan tertarik dengan bonus dan diskon yang diberikan penjual makanan dengan produk yang sama yang ingin dipesan. Sehingga konsumen akan memilih membeli di penjual yang memberikan fasilitas promosi tersebut. Kebanyakan konsumen akan tertarik dengan bonus dan diskon yang diberikan penjual makanan dengan produk yang sama yang ingin dipesan. Sehingga konsumen akan memiilih membeli di penjual tersebut dari pada penjual lain yang tidak memberikan bonus dan diskon pada produk yang sama.

Penelitian ini didukung oleh penelitian yang dilakukan Fiera Aryati Natakusumah, Ai Lili Yuliati (2016) yang menyimpulkan bahwa promosi berpengaruh yang signifikan terhadap keputusan pembelian. Hasil penelitin ini tidak sejalan dengan hasil penelitian dari Fazza Ilham Fachriza, Nadya Moeliono (2017) yang menyimpulkan bahwa 
promosi tidak berpengaruh signifikan terhadap keputusan pembelian.

Pengaruh Produk, Harga, Distribusi dan Promosi secara bersama-sama Terhadap Keputusan Pembelian

$\begin{array}{ccr}\text { Pengujian } & \text { secara } & \text { simultan } \\ \text { menunjukkan bahwa produk, harga, }\end{array}$ distribusi dan promosi secara bersama-sama berpengaruh secara signifikan terhadap keputusan pembelian. Hal ini dapat dilihat dari nilai sig. uji F sebesar $0,000<0,05$ maka Ho ditolak dan Ha diterima artinya produk, harga, distribusi dan promosi secara bersama-sama berpengaruh signifikan terhadap keputusan pembelian.

Hipotesis awal diterima dimungkinkan karena apabila produk (tampilan, ukuran porsi makanan, kemasan dari makanan, pilihan rasa, dan tambahan toping), harga yang sesuai, distribusi dan promosi dilihat sebagai satu kesatuan maka konsumen akan tertarik melakukan keputusan pembelian. Kombinasi Produk, Harga, dan Distribusi juga menjadi perpaduan yang komprehensif atas informasi yang dibutuhkan oleh calon pembeli. Dengan informasi yang komprehensif tersebut maka calon pembeli akan lebih mudah dan cepat dalam membuat keputusan membeli atau tidak membeli. Ini artinya variabel bauran pemasaran secara umum dapat menjawab situasi pasar konsumen aplikasi pengantaran makanan khususnya pada GoFood

Penelitian ini didukung oleh penelitian yang dilakukan oleh Suzy Widyasari dan Erna Triastuti Fifilia (2009) yang menyimpulkan bahwa produk, harga, distribusi dn promosi secara bersama-sama berpengaruh secara signifikan terhadap keputusan pembelian.

\section{KESIMPULAN}

Berdasarkan hasil analisis dan pembahasan, maka dapat ditarik kesimpulan bahwa produk berpengaruh signifikan terhadap keputusan pembelian melalui aplikasi Gofood pada mahasiswa Stiepar Api Yogyakarta. Fakta lain yang cukup menarik adalah bahwa harga tidak berpengaruh signifikan terhadap keputusan pembelian. Distribusi juga tidak berpengaruh signifikan terhadap keputusan pembelian melalui aplikasi Gofood pada mahasiswa Stiepar Api Yogyakarta. Namun demikian promosi berpengaruh signifikan terhadap keputusan pembelian melalui aplikasi Gofood pada mahasiswa Stiepar Api Yogyakarta. Adapun produk, harga, distribusi, promosi secara bersama-sama berpengaruh signifikan terhadap keputusan pembelian melalui aplikasi Gofood pada mahasiswa Stiepar Api Yogyakarta.

\section{DAFTAR PUSTAKA}

Abdurahman, N. H. 2015. Manajemen Strategi Pemasaran. Bandung: Pustaka Setia.

Armstrong, M., \& Chen, Y. 2017. Discount Pricing. In Munich Personal RePEc Archive (Issue January). https://mpra.ub.uni-

muenchen.de/76681/

Begum, V. 2015. Effects of Kellogg's Nutritional Label on Consumer Buying Behaviour in Dubai, UAE. Procedia Social and Behavioral Sciences, 211: 1195-1202. https://doi.org/10.1016/j.sbspro.2015.1 1.159

Blattberg, R. C., \& Briesch, R. A. (2012). Sales Promotions. In The Oxford Handbook of Pricing Management (Issue May). Oxford University Press. https://doi.org/10.1093/oxfordhb/97801 99543175.013.0024 
Buted, D. R., Felicen, S. S., \& Manzano, A. I. 2014. A Correlation Study between Student Performance in Food and Beverage Services Course and Internship in F\&B Department of Hospitality Business. International Journal of Academic Research in Business and Social Sciences, 4(6): 5466.

https://doi.org/10.6007/IJARBSS/v4$\mathrm{i} 6 / 924$

Deny, F dan Noor, I.R. 2020. Pengaruh Marketing Mix Terhadap Keputusan Pembelian Furnitur Pada PT. Catur Sentosa Berhasil.Jurnal Ecodemica, Vol. 4No. 1 April 2020

Duwi, P. 2010. Teknik Mudah Dan Cepat Melakukan Analisis Data Penelitian Dengan SPSS. Yogyakarta: Gava Media.

Dwinanda, G. dan Nur, Y. 2020. Bauran pemasaran $7 \mathrm{p}$ dalam mempengaruhi keputusan pembelian konsumen pada industri retail giant ekspres makassar. Jurnal Mirai Management e-ISSN : 2597 - 4084, Volume 6 No.1 202 https://journal.stieamkop.ac.id/index.ph p/mirai

Fachriza, F.I. dan Moeliono, N. 2017. Pengaruh Bauran Pemasaran Terhadap Keputusan Pembelian Rokok Mild. Jurnal Ecodemica, Vol. 1 No. 2 September 2017 Issn: 2355-0295, EIssn: 2549-8932

Gad Mohsen, M. and Dacko, S. 2013. "An Extension of the Benefit Segmentation Base for the Consumption of Organic Foods: A Time Perspective." Journal of Marketing Management 29(15-16): 1701-28.

http://www.tandfonline.com/doi/abs/10. 1080/0267257X.2013.800896.

Ghozali, I. 2009. Aplikasi Analisis

Multivariate Dengan Program SPSS.

Edisi Keempat, Penerbit Universitas Diponegoro.
Guiltinan, P. J. dan Gordon, W. P. 1992, Strategi dan Program Manajemen Pemasaran, Edisi 2, Erlangga, Jakarta.

Gupta, S., \& Cooper, L. G. 1992. The Discounting of Discounts and Promotion Thresholds. Journal of Consumer Research, 19(3), 401. https://doi.org/10.1086/209310

Hasan, A. 2008. Marketing. Media Utama. Yogyakarta

Hintze, S. 2015.Value Chain Marketing A Marketing Strategy to Overcome Immediate Customer Innovation Resistance, Springer International Publishing Switzerland.

Igir F.G.; Tampi, J. R. E; dan Taroreh H. 2018. Pengaruh Kualitas Produk Dan Harga Terhadap Keputusan Pembelian Mobil Daihatsu Grand Max Pick Up (Studi pada PT. Astra International Tbk Daihatsu Cabang Malalayang), Jurnal Administrasi Bisnis, Vol. 6, No.2, Hal:86-96

Kim, E.; Park, M.C.; Lee, J. 2017. Determinants of the intention to use BuyOnline, Pickup In-Store (BOPS): The moderating effects of situational factors and product type. Telemat. Informatics. 34 ,

1721-1735, doi:10.1016/j.tele.2017.08.006.

Kowalska, M. 2012. The internet impact on market behavior of young consummer. Journal of International Studies, 5(1): 101-106.

Kotler, P. dan Keller, L. K. 2009. Manajemen Pemasaran Jilid 1, Edisi 13, Jakarta: Erlangga

Kotler, P. dan Amstrong, G. 2001. Prinsipprinsip pemasaran, Edisi kedua belas, Jilid 1. Jakarta: Erlangga

-------. 2008. Prinsip-prinsip pemasaran jilid 1. Jakarta.Erlangga.

------- 2012. Prinsip-prinsip Pemasaran, Jilid 1, Edisi 13. Jakarta: Erlangga.

Kusrini, D. E., \& Kismanto, A. 2011. Market Potential Research For The 
Revitalization Of Traditional Markets. International Conference on Information Systems For Business Competitiveness (ICISBC): 159-164. http://eprints.undip.ac.id/36113/1/Dwi_ EndahK.pdf

Lee, M. H. et.al. 2018. How to respond to the Fourth Industrial Revolution, or the second information technology revolution? Dynamic new combinations between technology, market, and society through open innovation. Journal of Open Innovation: Technology, Market, and Complexity, 4(3). https://doi.org/10.3390/joitmc4030021

Lovelock, Christopher, and Jochen Wirtz. 2011. Services Marketing: People, Technology, Strategy, 7th Edition. Prentice Hall.

Meo, A., et al. 2014. "The Impact of Promotional Tools on Sales Promotion." Journal of Public Administration and Governance 4(2): 202-16.

www.macrothink.org/jpag\%5Cnhttp://d x.doi.org/10.5296/.

Mowen, J. C. dan Minor, M. 2002. Perilaku Konsumen. Jilid Pertama. Alihbahasa: Lina Salim. Jakarta: Erlangga.

Natakusumah, F.A. dan Yuliati, A.L. 2016. Pengaruh bauran pemasaran terhadap keputusan pembelian (studi pada ina cookies bandung). Jurnal Manajemen Teori dan Terapan Tahun 9. No. 1, April 2016.

Nielsen company. 2019. What's Next in Southeast Asia Seizing Untapped Opportunities in Asia, S. https://www.nielsen.com/wpcontent/uploads/sites/3/2019/06/whatsnext-in-southeast-asia.pdf. Diakses tanggal 3 Oktober 2021

Norrahmiati. 2016. Analisis pengaruh bauran pemasaran terhadap keputusan pembelian mobil Suzuki Ertiga di dealer Suzuki Banjarmasin. Jurnal Socio
Scientia, 8 (2): 1-10.

Oktavenia, K. A. R. dan Ardani, I. G. A. K. S. (2019). Pengaruh Kualitas Produk Terhadap Pembelian Handphone Nokia Dengan Citra Merek Sebagai Premediasi. E-Jurnal Manajemen Unud, 8 (3), 1374-1400.

Oktavianus, B.; Tinneke, M.; Tumbel, J. A. F. K. (2019). Pengaruh Marketing Mix Terhadap Keputusan Pembelian Pada CV. Justiti Motor Lembata. Jurnal Administrasi Bisnis, 8 (2), 34-42.

Pomering, A. 2017. "Marketing for Sustainability: Extending the Conceptualisation of the Marketing Mix to Drive Value for Individuals and Society at Large." Australasian Marketing Journal 25(2): 157-65.

Priatmoko, S., \& David, L. D. (2021). WINNING TOURISM DIGITALIZATION OPPORTUNITY IN THE INDONESIA CBT BUSINESS. GeoJournal of Tourism and Geosites, 800-806.

Priatmoko, S., \& Lóránt, D. (2021). A Story of a Cup of Coffee Review of Google Local Guide Review. Proceedings of the 4th Forum in Research, Science, and Technology (FIRST-T3-20), 1(January), 50-55.

Rathod, M. K. 2016. "A Study on Extended Marketing Mix." Advances in Economics and Business Management (AEBM) 3(2): 205-12.

Riduwan. 2008. Dasar-dasar Statistika. Bandung: Alfa Beta

Rionardo, P. dan Kazia, L. 2017. Pengaruh Bauran Pemasaran terhadap Keputusan Pembelian pada Bisnis Chepito tour \& travel. PERFORMA: Jurnal Manajemen dan Start-Up Bisnis, 2(3): 332-341

Sadeli, A. H.; Hesty N. U.; Rayi R. 2016. "Does Customer Satisfaction On Product Quality Illustrates Loyalty Of Agricultural Product?" International 
Journal of Applied Business and Economic Research ,14(1): 223-32.

Sambhanthan, Arunasalam, and Alice G. 2016. "Strategic Advantage in Web Tourism Promotion: An e-Commerce Strategy for Developing Countries." International Business: Concepts, Methodologies, Tools, and Applications: 597-618.

Simamora, Bilson. 2002. Panduan Riset Perilaku Konsumen. PT Gramedia Pustaka Utama, Jakarta

Skudiene, V; Vilte, A; and Laura, S. 2015. "Internationalization Model Revisited: E-Marketing Approach." Procedia Social and Behavioral Sciences 213: 918-24. http://dx.doi.org/10.1016/j.sbspro.2015. 11.505 .

Spáčil, V., \& Teichmannová, A. (2016). Intergenerational Analysis of Consumer Behaviour on the Beer Market. Procedia - Social and Behavioral Sciences, 220(March), 487-495. https://doi.org/10.1016/j.sbspro.2016.0 5.524

Sugiyono. 2002.Metode Penelitian Bisnis. PT.Gramedia Pustaka Utama, Jakarta.

Sumarwan, U. 2003. Perilaku Konsumen: Teori dan Penerapannya dalam Pemasaran, Cetakan Pertama, Jakarta: Ghalia Indonesia

Suzy, W. 2008. Analisis perilaku Brand Switching Konsumen Dalam Pembelian Produk Sepeda Motor.Jurnal Bisnis dan Ekonomi (JBE). 15 (2): 107-108.

Suzy, W. dan Erna, T. F. 2009. Analisis pengaruh produk, harga, promosi dan lokasi terhadap keputusan pembelian rumah (studi pada perumahan graha estetika semarang). TEMA 6 (2): 1159 169.

Swasta, B. dan Irawan.2014. Manajemen Pemasaran Modern, Liberty, Yogyakarta.

Tjiptono, F. 2011. Service Management Mewujudkan Layanan Prima. Edisi2. Yogyakarta: Andi., p.231)

Wachyuni, Sandi; Wiweka, Kadek; dan Liman, Melyana. 2018. PENGARUH ONLINE DISTRIBUTION CHANNELS (ODS) TERHADAP HOTEL REVENUE. Journal of Tourism and Economic, 1(2):64-72

Zulaicha, S. dan Irawati, R. 2016. Pengaruh Produk dan Harga Terhazdap Keputusan Pembelian Konsumen di Morning Bakery Batam. Inovbiz Jurnal Inovasi Bisnis, 4(2):123-136

Internet:

https://business.vic.gov.au/businessinformation/finance/pricing-forprofit/develop-discount-strategies Diakses 18 Oktober 2021

https://databoks.katadata.co.id/datapublish/2 019/12/03/96-pengguna-internet-diindonesia-pernah-gunakan-e-commerce . Diakses 5 november 2020.

https://databoks.katadata.co.id/datapublish/2 021/02/01/masa-depan-cerah-layananpesan-antar-makanan-daring-asiatenggara Diakses 20 Oktober 2021 